\title{
Peningkatan Motorik Halus Melalui Menjahit Jenis-Jenis Pola Baju pada TK Kelompok A
}

\author{
Kholifatur Rohmah*, Usep Kustiawan, Suryadi \\ Universitas Negeri Malang, Jl. Semarang No. 5 Malang, Jawa Timur, Indonesia \\ *Penulis korespondensi, Surel: kholifaturrohmahifa@gmail.com
}

Paper received: 5-7-2021; revised: 23-7-2021; accepted: 30-7-2021

\begin{abstract}
The results of observations made by researchers in group A kindergarten Plus wahidiyah Sukun. there are 12 children who get the BB and MB criteria, 3 children get BSH criteria, and 2 children get BSB criteria. Sewing activities are only done once so that the results obtained are not optimal. This research is a class action research, aims to determine the application and improvement of fine motor skills through sewing activities. The scope of this research is fine motor children aged 4-5 years, patterns in sewing are limited to the types of clothing patterns made from duplex paper, the indicators used in this study are: 1) eye and hand coordination for complex movements and 2) controlling hand movements using smooth muscles. Analysis of the data used are: Quantitative is used to look at classical and qualitative child development achievements to describe data from observations, interviews, and documentation. The research was conducted in 3 stages: pre-action, cycle I, and cycle II. The results of mastery learning in pre-action is 17.6 percent. These results are still very low so there is a need for further stimulus. Researchers prepare RPPH, assessments, and make media. The implementation of sewing activities consists of initial, core and closing activities. Observations were made during sewing activities. After the activity, a reflection is carried out. The results of mastery learning in the first cycle of the first meeting were 23.5 percent. The second meeting is 70.5 percent. Cycle II of the first meeting was 82.3 percent. The second meeting was 88.2 percent. The results of the second cycle of the second meeting had exceeded the specified criteria greater than or equal to 85 percent. Based on these data sewing activities of the types of clothing patterns can improve fine motor children in group A TK Plus Wahidiyah Sukun. Suggestions in this study the teacher can implement sewing activities to improve fine motor group A, especially when the sub-theme of clothing.
\end{abstract}

Keywords: : fine motor; sewing in early childhood; types of clothing patterns

\begin{abstract}
Abstrak
Hasil observasi yang dilakukan peneliti pada kelompok A TK Plus wahidiyah Sukun terdapat 12 anak yang mendapatkan kriteria BB dan MB, 3 anak mendapatkan kriteria BSH dan 2 anak mendapatkan kriteria BSB. Kegiatan menjahit hanya dilakukan 1 kali sehingga hasil yang diperoleh belum maksimal. Penelitian ini merupakan penelitian tindakan kelas, bertujuan untuk mengetahui penerapan dan peningkatan motorik halus melalui kegiatan menjahit. Ruang lingkup penelitian ini yaitu motorik halus anak usia 4-5 tahun, pola dalam kegiatan menjahit dibatasi pada jenis-jenis pola baju yang terbuat dari kertas duplex, indikator yang digunakan pada penelitian ini yaitu: 1) koordinasi mata dan tangan untuk melakukan gerakan yang rumit dan 2) mengontrol Gerakan tangan yang menggunakan otot halus. Analisis data yang digunakan yaitu: kuantitatif digunakan untuk melihat capaian perkembangan anak secara klasikal dan kualitatif untuk mendeskripsikan data hasil observasi, wawancara, dan dokumentasi. Penelitian dilakukan dalam 3 tahap: pra tindakan, siklus I, dan siklus II. Hasil ketuntasan belajar pada pra tindakan yaitu 17,6 persen. Hasil tersebut masih sangat rendah sehingga perlu adanya stimulus lebih lanjut. Peneliti menyusun RPPH, penilaian, dan pembuatan media. Pelaksanaan kegiatan menjahit terdapat kegiatan awal, inti dan penutup. Observasi dilakukan saat kegiatan menjahit. Selesai kegiatan maka dilakukan refleksi. Hasil ketuntasan belajar pada siklus I pertemuan pertama yaitu 23.5 persen. Pertemuan kedua 70.5 persen. Siklus II pertemuan pertama mendapatkan hasil 82.3 persen. Pertemuan kedua 88.2 persen. hasil pada siklus II pertemuan kedua sudah melebihi kriteria yang ditentukan sama dengan lebih dari 85 persen. Berdasarkan data tersebut kegiatan menjahit jenis-jenis pola baju dapat meningkatkan motorik halus anak kelompok A TK Plus Wahidiyah Sukun. Saran pada penelitian ini guru dapat
\end{abstract}


menerapkan kegiatan menjahit untuk meningkatkan motorik halus kelompok A, terutama pada saat sub tema pakaian.

Kata kunci: motorik halus; menjahit pada anak usia dini; jenis jenis pola baju

\section{Pendahuluan}

Perkembangan anak merupakan hal yang sangat penting terutama pada anak usia dini, ada 6 aspek perkembangan anak usia dini yaitu: nilai agama dan moral, fisik motorik, kognitif, sosial emosional, bahasa dan seni. Menurut (Mulyasa, 2014) anak usia dini atau biasa disebut masa prasekolah memiliki masa peka, masa tersebut merupakan masa yang paling tepat untuk meletakkan pondasi atau dasar untuk mengembangkan 6 aspek perkembangan anak dan semua potensi yang dimiliki oleh anak. Oleh karena itu sangat penting mengembangkan 6 aspek perkembangan pada anak, karena anak usia 0-8 tahun merupakan masa emas atau lebih sering dikenal dengan istilah golden age.

Diantara enam aspek tersebut salah satunya perkembangan fisik motorik. Perkembangan fisik motorik dibagi menjadi dua yaitu motorik kasar dan motorik halus. Menurut (Yamin \& Sanan, 2010) motorik kasar anak akan berkembang sesuai dengan usia yang dimiliki anak, sehingga orang dewasa tidak perlu memaksakan pertumbuhan motorik anak, seperti anak usia 6 bulan belum bisa duduk sendiri sehingga anak tersebut tidak perlu dipaksakan untuk duduk di kursi. Selain itu menurut Yamin \& Sanan ada beberapa kegiatan yang dapat dilakukan untuk meningkatkan motorik kasar anak yaitu: mencari jejak, berjalan naik turun tangga, bermain terowongan dan lain-lain. Sedangkan motorik halus menurut Yamin \& Sanan adalah kemampuan untuk mengembangkan gerak jari-jari tangan terutama jari telunjuk dan ibu jari. Misalnya: memegang, menggenggam, merobek, dan menggunting.

Berdasarkan hasil observasi dan wawancara dengan guru kelas TK A pada tanggal 25 November 2019 bertempat di TK Plus Wahidiyah Sukun kota Malang diperoleh data bahwa, anak kelompok A berjumlah 17 anak, yang terdiri dari 7 perempuan dan 10 laki-laki. Kegiatan yang sering dilakukan di lembaga TK Plus Wahidiyah dalam mengembangkan motorik halus yaitu: kegiatan menempel, finger painting dan kegiatan stempel. Kegiatan menjahit pernah dilakukan satu kali di kelompok A, hasil yang diperoleh pada kegiatan menjahit tersebut yaitu dari 17 anak yang ada pada kelompok A, sekitar 70\% atau 12 anak yang kurang dalam perkembangan motorik halusnya, sedangkan 20\% atau 3 anak bisa mengikuti kegiatan menjahit walaupun masih kesulitan, dan sisanya $10 \%$ atau 2 anak sudah bisa melakukan menjahit sesuai dengan arahan atau petunjuk guru.

Berdasarkan hasil observasi dan wawancara di atas bahwa perkembangan motorik halus anak kelompok A di TK Plus Wahidiyah Sukun belum berkembang dengan baik. Terutama karakteristik motorik halus usia 4-5 tahun no 3 dan 6 pada permendikbud no 137 tahun 2014 yaitu: 1. Mengkoordinasikan mata dan tangan untuk melakukan gerakan yang rumit; 2. Mengontrol gerakan tangan yang menggunakan otot halus. Hasil dari pengamatan tersebut peneliti menduga berapa faktor penyebab masalah diantaranya sebagai berikut: 1 ). Guru masih kurang menginovasi dalam merancang kegiatan yang meningkatkan motorik halus; 2). Anak jarang melakukan kegiatan menjahit sehingga hasil yang diperoleh kurang memuaskan; 3). Anak kelompok A adalah usia awal dimana seluruh perkembangan anak belum optimal, sehingga diperlukan stimulus-stimulus yang tepat dalam meningkatkan seluruh 
perkembangan pada anak. Berdasarkan beberapa faktor penyebab tersebut, peneliti memberikan beberapa alternatif pemecahan masalah antara lain yaitu: 1). Menerapkan kegiatan baru atau menginovasi kegiatan yang sudah ada dalam meningkatkan motorik halus anak; 2). Menerapkan kegiatan menjahit lebih sering daripada sebelumnya. Berdasarkan hasil wawancara dengan guru kelompok A di TK Plus Wahidiyah, kegiatan menjahit pernah diterapkan satu kali dan hasil dari kegiatan menjahit kurang memuaskan. Setelah itu belum ada tindak lanjut untuk kegiatan menjahit.

Hipotesis tindakan dalam penelitian ini, jika kegiatan menjahit jenis-jenis pola baju dilaksanakan dalam pembelajaran di kelompok A TK Plus Wahidiyah Sukun Malang maka perkembangan fisik motorik halus pada anak dapat meningkat.

\section{Metode}

Penelitian ini merupakan jenis penelitian tindakan kelas, menggunakan model Kemmis dan Mc Taggart, yang sering dikenal dengan model spiral. Menurut (Akbar, 2009) penelitian tindakan kelas merupakan sebuah proses investigasi terkendali dalam menemukan sebuah masalah pada proses pembelajaran di kelas dan juga bagaimana cara menangani masalah tersebut. Penelitian tindakan kelas dilakukan secara bersiklus, dengan tujuan untuk memecahkan masalah tersebut serta meningkatkan proses pembelajaran yang ada di dalam kelas. Penelitian ini terdapat tiga tahap yaitu: pra tindakan, siklus I dan siklus II, setiap siklus terdiri atas: 1). perencanaan (planning); 2). tindakan (action); 3). observasi (observing) dan; 4). refleksi (reflecting). Pada penelitian ini setiap siklus terdapat dua pertemuan yaitu pertemuan pertama dan pertemuan kedua.

Pelaksanaan dalam penelitian ini menggunakan PTK model kolaboratif, dimana peneliti berkolaborasi dengan seorang kolaborator yakni guru kelompok A TK Plus Wahidiyah Sukun kota Malang. peneliti bertindak sebagai perencana kegiatan, pengumpulan data, penganalisa dan pelapor hasil penelitian. Guru kelas bertugas sebagai pelaksana kegiatan, menjadi teman diskusi pada saat kegiatan refleksi.

Penelitian ini dilakukan di TK Plus Wahidiyah Jl. Kolonel Sugiono Gg 06, No 75, Rt 05, Rw 06, Kelurahan Gadang, Kecamatan Sukun, Kota Malang. Kelompok yang akan diteliti yakni kelompok A dengan jumlah 17 anak yang terdiri dari 7 anak perempuan dan 10 anak laki-laki. Dilaksanakan pada semester II Tahun Ajaran 2019/2020.

Teknik pengumpulan data pada penelitian ini yaitu: observasi, wawancara, dan dokumentasi. Observasi digunakan untuk mengumpulkan data tentang kemampuan motorik halus anak dalam melakukan kegiatan menjahit. Kemampuan motorik halus anak dapat diamati saat anak melakukan kegiatan menjahit yaitu: anak memasukkan tali kedalam lubang sesuai dengan alur yang sudah dicontohkan, anak menyelesaikan jahitan sampai akhir, anak menggabungkan kedua ujung tali dengan cara ditali berbentuk pita, anak mewarnai hasil jahitan pola baju menggunakan spidol warna. Wawancara digunakan oleh peneliti untuk mendapatkan informasi tentang permasalahan dan penyebab munculnya masalah tersebut dalam proses kegiatan pembelajaran di kelas, serta belajar anak di kelas. Wawancara dilakukan kepada guru. Dokumentasi yang dimaksud dalam penelitian ini adalah dokumentasi foto yang digunakan untuk mengumpulkan data tentang berbagai peristiwa sebelum maupun saat proses pembelajaran dilakukan. 
Instrumen pengumpulan data yaitu: 1). Lembar observasi digunakan untuk menilai kemampuan motorik halus anak melalui kegiatan menjahit jenis-jenis pola baju, dalam instrumen ini aspek yang dinilai yaitu: anak memasukkan tali kedalam lubang sesuai dengan alur yang sudah dicontohkan, anak menyelesaikan jahitan sampai akhir, anak menggabungkan kedua ujung tali dengan cara ditali berbentuk pita, anak menghias hasil jahitan pola baju menggunakan pensil warna, spidol atau krayon. 2). Pedoman wawancara digunakan untuk mengetahui permasalahan, kesan dan saran ketika pembelajaran kegiatan menjahit. Wawancara dilakukan oleh peneliti dengan guru kelompok A. 3). Instrumen dokumentasi digunakan untuk mendokumentasikan RPPH dan kegiatan-kegiatan yang dilakukan selama proses pembelajaran ketika anak melakukan kegiatan menjahit.

Analisis data yang digunakan dalam penelitian ini yaitu analisis data kualitatif, dimana peneliti menggunakan deskriptif dari data hasil observasi, wawancara, dan dokumentasi. Analisis data kuantitatif yaitu digunakan untuk melihat capaian perkembangan anak secara klasikal. Kriteria keberhasilan siswa yaitu 65\% sedangkan untuk kriteria ketercapaian belajar secara klasikal yaitu $\geq 85 \%$.

\section{Hasil dan Pembahasan}

\subsection{Hasil}

\subsubsection{Pra Tindakan}

Penelitian ini dilakukan dalam 3 tahap yaitu: pra tindakan, siklus I, dan siklus II. Penelitian pra tindakan dilakukan pada tanggal 18 Februari 2020. Subjek yang akan diteliti yaitu kelompok A usia 4-5 tahun bertempat di TK Plus Wahidiyah Sukun Kota Malang. Pada penelitian ini peneliti sebagai perancang kegiatan dan observer sedangkan guru kelas sebagai pelaksana kegiatan. Pada penelitian pra tindakan indikator yang digunakan dalam kegiatan menjahit ada 2 yaitu: ketuntasan hasil jahitan dan mewarnai hasil jahitan tanpa keluar dari garis. Berikut hasil dari kegiatan menjahit akan dipaparkan pada tabel 1.

Tabel 1. Hasil Kegiatan Menjahit Pra Tindakan

\begin{tabular}{ccccccc}
\hline Jumlah keseluruhan anak & BB & MB & BSH & BSB & Rata-rata & $\begin{array}{c}\text { Ketuntasan belajar } \\
\text { secara klasikal }\end{array}$ \\
\hline 17 & 9 & 5 & 3 & 0 & 49.2 & $17.6 \%$ \\
\hline
\end{tabular}

Hasil kegiatan menjahit pada pra tindakan yaitu terdapat tiga anak yang berkembang sesuai harapan (BSH). Lima anak yang mulai berkembang (MB) lalu ada sembilan anak yang belum berkembang (BB). Hasil ketuntasan belajar yang diperoleh yaitu 17.6\%. Perkembangan motorik halus anak masih kurang dalam kegiatan menjahit. Karena ketuntasan belajar secara klasikal dikatakan berhasil jika mencapai $\geq 85 \%$. Hasil data diatas diketahui bahwa motorik halus anak kelompok A dalam kegiatan menjahit masih rendah sehingga perlu distimulus sampai perkembangan motorik halus anak berkembang sesuai harapan.

\subsubsection{Siklus I}

Tahap pelaksanaan dan observasi dilakukan secara bersamaan, dalam penelitian ini guru kelas sebagai pelaksana, peneliti sebagai observer dan dibantu dengan teman sejawat 
dalam melakukan kegiatan dokumentasi. Pelaksanaan siklus I pertemuan pertama dilaksanakan pada tanggal 25 Februari 2020. Sedangkan siklus I pertemuan kedua dilaksanakan pada tanggal 27 Februari 2020. Sebelum melakukan Tindakan siklus I langkah pertama menyusun RPPH siklus I pertemuan pertama dengan sub tema helikopter, dan sub tema roket pada siklus I pertemuan kedua. Langkah kedua menyiapkan media yang akan digunakan pada kegiatan menjahit seperti tali pita, pola baju dari kertas karton yang bergambar helikopter dan roket, spidol warna dan lain-lain. Langkah ketiga menyusun instrumen penilaian. Indikator penilaian yang akan digunakan pada kegiatan menjahit ada 4 yaitu: ketuntasan hasil jahitan, kesesuaian alur jahitan, menali berbentuk pita, dan mewarnai gambar yang ada pada pola baju tanpa keluar dari garis.

Tabel 2. Hasil Kegiatan Menjahit Siklus I

\begin{tabular}{cccccccc}
\hline No & Penelitian Siklus I & $\begin{array}{c}\text { Jumlah } \\
\text { Keseluruhan Anak }\end{array}$ & BB & MB & BSH & BSB & $\begin{array}{c}\text { Ketuntasan Belajar } \\
\text { Secara Klasikal }\end{array}$ \\
\hline 1. & Pertemuan pertama & 17 & 5 & 8 & 4 & 0 & $23.5 \%$ \\
2. & Pertemuan kedua & 17 & 0 & 5 & 4 & 8 & $70.5 \%$ \\
\hline
\end{tabular}

Hasil dari penelitian siklus I pertemuan pertama yang dilaksanakan pada tanggal 25 Februari 2020, terdapat 5 anak yang belum berkembang (BB), 8 anak berada pada kriteria mulai berkembang (MB) dan 4 anak sudah berkembang sesuai harapan (BSH). Anak dikatakan tuntas apabila mendapatkan nilai $\geq 65$, skor tersebut terletak pada kriteria BSH dan BSB. Hasil anak yang tuntas pada siklus I pertemuan pertama berjumlah 4 anak. Ketuntasan belajar secara klasikal pada pertemuan pertama mendapatkan hasil 23.5\%. Hasil tersebut belum memenuhi kriteria ketuntasan belajar secara klasikal yang sudah ditentukan, yaitu $\geq 85 \%$. Diantara 17 anak pada kelompok A masih ada 13 anak yang belum tuntas, sehingga peneliti melanjutkan penelitian pada pertemuan kedua.

Hasil siklus I pertemuan kedua yaitu terdapat 8 anak berada pada kriteria berkembang sangat baik (BSB), 4 anak ada pada kriteria berkembang sesuai harapan (BSH) dan 5 anak berada pada kriteria mulai berkembang (MB). Ketuntasan belajar secara klasikal pada siklus I pertemuan kedua yaitu 70.5\%. Hasil tersebut meningkat pesat karena adanya perbaikan media yang digunakan pada saat kegiatan menjahit, walaupun hasil yang diperoleh meningkat pesat tetapi hasil tersebut belum memenuhi kriteria yang sudah ditentukan yaitu $\geq 85 \%$, sehingga peneliti tetap melanjutkan pada siklus II.

Selesai melaksanakan siklus I maka dilakukan kegiatan refleksi. Refleksi sangat diperlukan dalam kegiatan pembelajaran, dengan adanya refleksi diharapkan dapat mengurangi kesalahan-kesalahan yang dilakukan pada pembelajaran sebelumnya agar mendapatkan hasil yang baik pada pembelajaran berikutnya. Ada beberapa kekurangan dari kegiatan menjahit pola baju pada siklus I antara lain: 1) tali pita yang panjang dan ujung tali mudah terburai ketika digunakan untuk menjahit, 2) guru terlalu singkat dalam menjelaskan kegiatan menjahit pada anak-anak, sehingga banyak anak-anak yang masih belum paham. Perbaikan dari permasalahan tersebut sudah dilaksanakan seperti memperbaharui ujung pita yang mudah terburai sehingga membakar ujung pita, pada pertemuan kedua peneliti juga mendapatkan saran untuk memberi selotip pada ujung pita agar pita menjadi runcing dan lebih mudah digunakan, permasalahan kedua seharusnya guru menjelaskan kegiatan menjahit setengah dari pola baju tersebut agar anak-anak lebih faham dan mendapatkan kesempatan 
lebih lama dalam memperhatikan guru saat menjelaskan kegiatan menjahit tersebut. Peneliti dan guru bekerja sama dalam memperbaiki masalah-masalah tersebut dan menerapkannya pada siklus selanjutnya, agar mendapatkan hasil sesuai yang diharapkan.

\subsubsection{Siklus II}

Pelaksanaan siklus II Pertemuan pertama dilaksanakan pada tanggal 2 Maret 2020, sedangkan pertemuan kedua dilaksanakan pada tanggal 5 Maret 2020. Peneliti dibantu oleh guru dalam melaksanakan kegiatan menjahit, sedangkan peneliti sebagai observer dan dibantu oleh teman sejawat dalam pengambilan dokumentasi. Sebelum melaksanakan penelitian siklus II. Langkah pertama yaitu menyusun RPPH siklus I pada pertemuan pertama dengan tema alam semesta, sub-sub tema air dan pada siklus II pertemuan kedua dengan sub-sub tema pasir. Langkah kedua menyiapkan media yang akan digunakan pada siklus II, media sudah diperbaharui sesuai dengan refleksi dari siklus I. Langkah ketiga Menyusun instrumen penilaian. Indikator penilaian yang akan digunakan pada kegiatan menjahit ada 4 yaitu: ketuntasan hasil jahitan, kesesuaian alur jahitan, menali berbentuk pita, dan mewarnai gambar yang ada pada pola baju tanpa keluar dari garis.

Tabel 3. Hasil Kegiatan Menjahit Siklus II

\begin{tabular}{llcccccc}
\hline No & Penelitian Siklus II & $\begin{array}{c}\text { Jumlah } \\
\text { Keseluruhan Anak }\end{array}$ & BB & MB & BSH & BSB & $\begin{array}{c}\text { Ketuntasan Belajar } \\
\text { Secara Klasikal }\end{array}$ \\
\hline 1. & Pertemuan pertama & 17 & 0 & 3 & 2 & 12 & $82.3 \%$ \\
2. & Pertemuan kedua & 17 & 0 & 2 & 2 & 13 & $88.2 \%$ \\
\hline
\end{tabular}

Hasil kegiatan menjahit pada siklus II pertemuan pertama terdapat 3 anak yang mendapatkan kriteria mulai berkembang (MB), 2 anak yang mendapatkan kriteria berkembang sesuai harapan (BSH) dan 12 anak yang mendapatkan kriteria berkembang sangat baik (BSB). Hasil ketuntasan belajar secara klasikal pada pertemuan pertama yaitu 8.23\%. Hasil tersebut belum memenuhi kriteria yang sudah ditetapkan yaitu $\geq 85 \%$ sehingga peneliti memutuskan untuk melanjutkan penelitian siklus II pada pertemuan kedua. Hasil siklus II pertemuan kedua terdapat 2 anak yang mendapatkan kriteria mulai berkembang (MB), 2 anak mendapatkan kriteria berkembang sesuai harapan (BSH) dan 13 anak mendapatkan kriteria berkembang sangat baik (BSB). Total jumlah anak yang tuntas pada siklus II pertemuan kedua yaitu 15 anak dan 2 anak yang belum tuntas. Hasil ketuntasan belajar secara klasikal pada siklus II yaitu $88.2 \%$ hasil tersebut sudah melebihi dari kriteria yang sudah ditetapkan yaitu $\geq 85 \%$.

Siklus II pertemuan kedua selesai pada tanggal 5 Maret 2020. Selesai melakukan siklus II maka kegiatan selanjutnya refleksi. Pada kegiatan refleksi terdapat beberapa temuan dari kegiatan menjahit untuk meningkatkan motorik halus diantaranya: 1) kegiatan menjahit jenisjenis pola baju untuk meningkatkan motorik halus pada siklus II terlaksana dengan baik, 2) kemampuan motorik halus anak kelompok A semakin meningkat melalui kegiatan menjahit jenis-jenis pola baju, 3) ada dua anak yang belum mencapai kriteria yang sudah ditentukan, dikarenakan anak terlalu terburu-buru dalam mengerjakan sehingga hasil yang didapatkan tidak mencapai kriteria yang ditentukan, 4) hasil ketuntasan belajar secara klasikal pada siklus II pertemuan kedua yaitu $88.2 \%$, 5) Peneliti tidak perlu melanjutkan penelitian lebih lanjut karena hasil yang didapatkan sudah memenuhi kriteria yang sudah ditetapkan. 


\subsection{Pembahasan}

Kegiatan menjahit jenis-jenis pola baju diawali dengan menyusun rencana pelaksanaan pembelajaran harian (RPPH) sesuai dengan tema yang ada di sekolah dan menyusun instrumen penilaian, kemudian membuat media yang akan digunakan untuk menjahit yaitu pola baju dari kertas karton pada bagian atas pola baju diberi gambar tema pada hari itu seperti helikopter, gambar tersebut akan digunakan untuk mewarnai oleh anak-anak. Kemudian menyiapkan tali dan spidol warna yang akan digunakan untuk menjahit dan mewarnai gambar tersebut. Langkah-langkah kegiatan menjahit jenis-jenis pola baju sesuai dengan Langkahlangkah yang diungkapkan oleh (Irma, 2012) yaitu anak mengambil pola baju yang sudah berlubang kemudian anak memasukkan tali pada lubang pertama dan menarik tali tersebut kemudian memasukkannya kelubang kedua begitu seterusnya sampai selesai, setelah selesai sisa tali disambung dan ditali menjadi bentuk pita setelah selesai menali anak mewarnai gambar yang ada pada pola baju menggunakan spidol warna.

Anak usia dini berada pada proses pertumbuhan sehingga sangat penting untuk menstimulus semua aspek perkembangan terutama fisik motorik. Salah satu menstimulus motorik di taman kanak-kanak yaitu dengan kegiatan menjahit. Kegiatan menjahit dapat meningkatkan motorik halus seperti yang diungkapkan oleh (Hutauruk, 2008) kegiatan menjahit salah satu kegiatan yang sering diterapkan oleh guru di taman kanak-kanak untuk meningkatkan motorik halus pada anak.

Titik tekan pembelajaran motorik menurut Davc dalam (Decaprio, 2013) ada 5 yaitu: peniruan, manipulasi, ketelitian, artikulasi, pengalamiahan. Titik tekan tersebut sangat penting diterapkan pada pembelajaran motorik. Pada kegiatan menjahit ada 4 indikator yang dinilai yaitu ketuntasan hasil jahitan, kesesuaian alur, menali berbentuk pita, dan mewarnai gambar tanpa keluar dari garis. Salah satu titik tekan pembelajaran motorik yaitu peniruan, dalam kegiatan menjahit anak meniru bagaimana cara menjahit yang baik dan benar sesuai alur yang dicontohkan, jika anak sudah bisa mengikuti alur yang sudah dicontohkan maka kegiatan motorik berhasil. Pada penelitian pra tindakan dan siklus I pertemuan pertama masih banyak anak yang hasil jahitannya belum sesuai dengan yang dicontohkan oleh guru. Pada siklus I pertemuan kedua anak-anak sudah mulai paham, sebanyak 11 anak sudah bisa menjahit sesuai alur dan 6 orang anak masih berada pada tahap mulai berkembang (MB) dan belum berkembang (BB). Sedangkan pada siklus II anak-anak sudah mulai berada pada tahap berkembang sesuai harapan (BSH) dan berkembang sangat baik (BSB).

Capaian perkembangan motorik halus anak usia 4-5 tahun menurut permendikbud no 137 tahun 2014 tentang standar nasional pendidikan anak usia dini salah satunya yaitu mengkoordinasikan mata dan tangan untuk melakukan gerakan yang rumit, kegiatan menjahit merupakan salah satu kegiatan yang membutuhkan koordinasi antara mata dan tangan, sejalan dengan pendapat (Sukmawati, 2018) yang mengatakan bahwa menjahit merupakan kegiatan yang membutuhkan kesabaran, ketelitian keuletan dalam menggunakan alat-alat menjahit seperti jarum benang dan alat-alat jahit lainnya. Kegiatan menjahit seperti memasukkan tali pada lubang dan juga menali berbentuk pita, kegiatan tersebut membutuhkan koordinasi mata dan tangan dan juga ketelitian dalam memasukkan tali pada lubang.

Hasil ketuntasan belajar secara klasikal pada penelitian pra tindakan yaitu $17.6 \%$. Hasil tersebut menandakan bahwa motorik halus anak pada kegiatan menjahit masih belum berkembang, sehingga perlu adanya stimulus lebih lanjut untuk meningkatkan motorik halus 
anak kelompok A di TK Plus Wahidiyah. Peneliti melakukan kegiatan menjahit pada siklus I pertemuan pertama pada tanggal 25 Februari 2020 dan mendapatkan hasil $23.5 \%$ hasil tersebut juga masih jauh dari yang diharapkan sehingga peneliti melanjutkan pada pertemuan kedua yang dilakukan pada tanggal 25 Februari, hasil ketuntasan belajar yang diperoleh yaitu $70.5 \%$ hasil tersebut meningkat pesat dari siklus I pertemuan pertama, salah satu faktor peningkatan motorik halus anak karena adanya perbaikan media yang digunakan pada pertemuan kedua dan anak-anak juga sudah mulai paham dengan kegiatan menjahit yang baik dan benar. Hasil pada siklus I pertemuan kedua memang meningkat akan tetapi hasil tersebut belum memenuhi kriteria yang ditentukan sehingga peneliti akan melanjutkan penelitian lebih lanjut pada siklus II. Ketuntasan belajar secara klasikal pada siklus II pertemuan pertama mendapatkan hasil $82.3 \%$ hasil tersebut juga belum memenuhi kriteria yang telah ditetapkan oleh peneliti yaitu $\geq 85 \%$ sehingga peneliti melanjutkan pada pertemuan kedua. Pada pertemuan kedua mendapatkan hasil $88.2 \%$. hasil pada siklus II pertemuan kedua sudah melebihi kriteria yang ditentukan yaitu $\geq 85 \%$ sehingga kegiatan menjahit jenis-jenis pola baju dapat dikatakan berhasil, sesuai dengan depdikbud tahun 1994 dalam (Daryanto, 2011) yang menyatakan bahwa kelas dinyatakan tuntas belajar apabila $85 \%$ anak sudah mencapai nilai $\geq 65$. Hasil siklus II pertemuan kedua sudah memperoleh hasil sesuai yang diharapkan dan sudah mencapai kriteria yang ditentukan yaitu $\geq 85 \%$, sehingga peneliti tidak perlu melakukan penelitian lebih lanjut.

Manfaat kegiatan menjahit pada anak usia dini yaitu dapat menstimulus beberapa aspek perkembangan pada anak seperti aspek sosial emosional. Saat kegiatan menjahit anak-anak belajar sabar dalam memasukkan tali pada lubang yang membutuhkan ketelitian pada saat melakukan kegiatan tersebut, seperti yang dikatakan oleh (Sukmawati, 2018) bahwa menjahit adalah kegiatan yang membutuhkan kesabaran ketelitian dan keuletan dalam menggunakan alat-alat menjahit seperti jarum, benang dan alat-alat lainnya. Selain menstimulus aspek sosial emosional, kegiatan menjahit juga dapat meningkatkan motorik halus pada anak, seperti hasil yang diperoleh pada kegiatan menjahit jenis-jenis pola baju di TK Plus Wahidiyah yang selalu meningkat pada setiap pertemuan dari penelitian pra tindakan sampai siklus II. Hal tersebut sejalan dengan pendapat (Hutauruk, 2008) kegiatan menjahit merupakan kegiatan yang sering dilakukan oleh guru di taman kanak-kanak untuk meningkatkan motorik halus anak.

\section{Simpulan}

Kegiatan menjahit jenis-jenis pola baju pada anak kelompok A TK Plus Wahidiyah Sukun Kota Malang berjalan dengan baik. Hasil kegiatan menjahit jenis-jenis pola baju pada setiap pertemuan selalu meningkat, dari penelitian pra tindakan hingga siklus II. Ketercapaian kelas secara klasikal pada pra tindakan mendapatkan hasil $17.6 \%$ hasil pada penelitian pra tindakan menunjukkan perkembangan motorik halus anak pada kegiatan menjahit masih banyak yang belum berkembang, sehingga perlu adanya stimulus lebih lanjut. Peneliti melakukan tindakan siklus I pada pertemuan pertama hasil ketuntasan belajar secara klasikal yang diperoleh yaitu $23.5 \%$, sedangkan pada pertemuan kedua mendapatkan hasil $70.5 \%$ hasil tersebut sangat meningkat dari pertemuan pertama, meskipun meningkat hasil tersebut belum memenuhi kriteria yang sudah ditentukan sehingga peneliti tetap melanjutkan penelitian ke siklus II. Pada siklus II pertemuan pertama mendapatkan hasil $82.3 \%$ hasil tersebut juga belum memenuhi kriteria yang ditetapkan yaitu $\geq 85 \%$ sehingga peneliti melanjutkan pada pertemuan kedua dan mendapatkan hasil $88.2 \%$. hasil tersebut sudah melebihi dari kriteria yang ditentukan sehingga peneliti tidak perlu melakukan penelitian lebih lanjut. 
Jurnal Pembelajaran, Bimbingan, dan Pengelolaan Pendidikan, 1(7), 2021, 516-524

\section{Daftar Rujukan}

Akbar, S. (2009). Penelitian Tindakan Kelas. Yogyakarta: Cipta Media Aksara.

Daryanto. (2011). Penelitian Tindakan Kelas dan Penelitian Tindakan Sekolah. Yogyakarta: Gava Media.

Decaprio, R. (2013). Aplikasi Teori Pembelajaran Motorik Di Sekolah (Z. Perdana, ed.). Jogjakarta: DIVA Press.

Hutauruk. (2008). Keterampilan Umum Menjahit. Bogor: Indo Book Citra Media.

Irma, S. (2012). Peningkatan Kemampuan Motorik Halus Anak Melalui Permainan Menjahit Bervariasi Di Taman kanak-kanak Aisyiyah 3 Duri. Pesona Paud, 1(1).

Mulyasa. (2014). Manajmeen PAUD (P. Latifah, ed.). Bandung: PT Remaja Rosdakarya.

Sukmawati, T. (2018). Upaya LKP Lucky Dalam Meningkatkan Keterampilan Melalui Program Kursus Menjahit (Studi Kualitatif bagi kalangan perempuan di LKP Lucky desa Tanimulya kecamatan Ngamprah Kab. Bandung barat). Comm-Edu, 1(20), 30-37.

Yamin, M., \& Sanan, J. S. (2010). Panduan Pendidikan Anak Usia Dini (S. Ibad, ed.). Jakarta: Gaung Persada. 